Marlene Sjöberg är doktorand i ämnesdidaktik med inriktning mot naturvetenskapens didaktik vid forskarskolan CUL samt universitetsadjunkt vid Institutionen för didaktik och pedagogisk profession vid Göteborgs universitet. Hennes forskningsintressen rör lärande och undervisning inom naturvetenskap, med ett särskilt fokus på samtalets möjligheter för lärares lärande och professionsutveckling. Hon har omfattande undervisningserfarenhet från grundskolans senare del i naturorienterande ämnen och matematik.

Åke Ingerman är professor i ämnesdidaktik med inriktning mot naturvetenskapens och teknikens didaktik vid Institutionen för didaktik och pedagogisk profession vid Göteborgs universitet. Han är brett intresserad av undervisning och lärande inom naturvetenskap och teknik, både inom högre utbildning och grundskolan, och har forskat om både elevers och lärares lärande. Han har omfattande erfarenhet av fenomenografi och variationsteori som metodologisk ansats och har även intresserat sig för metodfrågor inom denna tradition.

Eva Nyberg är lektor i ämnesdidaktik vid institutionen för didaktik och pedagogisk profession vid Göteborgs universitet,. Hennes forskningsintressen rör undervisning och lärande i naturvetenskap, både i grundskolan och i högre utbildning, bl.a rörande formativ utvärdering med särskild inriktning på utveckling av lärares ämnesdidaktiska kompetens. Eva Nyberg har omfattande erfarenhet av lärarfortbildning avseende naturvetenskaplig undervisning och formativ utvärdering och har genomfört aktionsforskningsstudier i dessa sammanhang

\title{
MARLENE SJÖBERG
}

Institutionen för didaktik och pedagogisk profession vid Göteborgs universitet, Sverige marlene.sjoberg@gu.se

\section{ÅKE INGERMAN}

Institutionen för didaktik och pedagogisk profession vid Göteborgs universitet, Sverige ake.ingerman@gu.se

\section{EVA NYBERG}

Institutionen för didaktik och pedagogisk profession vid Göteborgs universitet, Sverige eva.nyberg@ped.gu.se

\section{Kvalitativa skillnader i lärares samtal om bedöm- ning och elevers kunnande i naturvetenskap}

\author{
Abstract \\ In this study we investigate teachers' collegial discussions about students' science knowledge, in a \\ context of collaborative planning and evaluation of teaching concerning the human body. The empi- \\ rical data consists of recordings of four meetings with researchers and one team of science teachers \\ in a Swedish compulsory school. This study contributes to the understanding of collegial discussions \\ as such and in particular what the teachers attend to as salient science knowledge. Making use of \\ a phenomenographic approach, the result consists of a set of categories of teachers' qualitatively \\ different ways of expressing students' science knowledge. When teachers relate the students' science
}


knowledge to their teaching it opens for an interdependent approach to teaching and assessment, in contrast to an instrumental way of viewing scientific knowledge, particularly in grading situations. We discuss how the identified qualitative differences have implications for teachers' possibilities of professional development, e.g. regarding subject didactical knowledge.

\section{INTRODUKTION}

Kunskaper om elevers lärande är kärnan i lärarens kompetens, menar Carlgren och Marton (2000), samtidigt som de pekar på ett stort behov av en gemensam professionell kunskapsbas för att diskutera olika ingående delar i processen från uttolkning av mål till bedömning av elevers kunskaper (a.a.). En sådan diskussion innefattar, menar de, en belysning av sambandet mellan undervisning och lärande.

Bedömning kan ses som en brygga mellan undervisning och elevers lärande (Wiliam, 2010). När lärare gör bedömningar för att förändra pågående undervisning i syfte att stärka elevernas möjligheter till lärande sker bedömningarna i formativt syfte (Wiliam, 2010). Bedömning av elevers lärande kan därför bidra till utveckling av undervisning och således kan undervisning, bedömning och elevers lärande ses som sammanvävda. Detta skriver också Wallace och Loughran (2012) utifrån studier av lärares lärande om undervisning i naturvetenskap och menar att istället för att se undervisning och lärande i naturvetenskap som separata aktiviteter bör de ses som samspelande.

Bedömningar av elevers kunnande genomförs även i summativt syfte, vilket i sin ytterlighet representeras av ett sammanfattande betyg. I Sverige används betyg som urvalsinstrument för påföljande utbildningsnivå, vilket är ovanligt i ett internationellt perspektiv (Lundahl, Hultén, Klapp \& Mickwitz, 2015). Lärares betygssättning, en myndighetsutövning som i Sverige kräver lärarlegitimation, ställer därmed krav på en likvärdig bedömning. Rimligheten i kravet på likvärdig bedömning är dock ifrågasatt (se exempelvis Gustafsson, Cliffordson \& Erickson, 2014).

Oavsett likvärdighetsprincipen och syftet med bedömning så är bedömning av elevers kunnande en del av lärares yrkeskunnande. Lärarens uppfattning om vad som ska bedömas när det gäller skolans naturvetenskap är då avgörande (Magnusson, Krajcik \& Borko, 1999). I en studie där sambandet mellan undervisning och bedömning var i fokus, studerades hur skolor kan stödjas vid bedömning av elevers kunnande (Quartz, Kawasaki, Sotelo \& Merino, 2014). Lärarna i studien uppmuntrades att artikulera sin tidigare tysta kunskap om elevernas önskvärda färdigheter och förmågor. Studien visade att artikuleringen var nödvändig för att kunna diskutera sambanden mellan vad eleverna skulle lära sig och planering och utvärdering av undervisning (ibid).

Den sammansatta kunskap lärare har om bedömning kan betecknas som bedömningskompetens eller förmåga att bedöma elevers kunnande. I internationell litteratur benämns den kompetensen eller förmågan exempelvis som 'assessment literacy' (Abell \& Siegel, 2011; Popham, 2009; Willis, Adie \& Klenowski, 2013), 'assessment capabilities' (Edwards, 2013) eller 'assessment expertise' (Lyon, 2013). Det finns dock ännu inte någon konsensus om vare sig benämning av begreppet eller dess innebörd (Willis et al., 2013).

I samtliga ovan nämnda såväl teoretiska som empiriska studier berörs sambandet mellan undervisning, bedömning och elevers lärande, men på skilda sätt och med olika utgångspunkter. Lärares bedömningskompetens kan även diskuteras i relation till teorier om lärares lärande. Willis et al. (2013) använder ett sociokulturellt perspektiv och betonar att bedömningskompetens inte är en bestämd uppsättning av förmågor, utan snarare en förmåga som är situerad och bör förstås i sin kontext och bedömningskultur.

Utifrån omfattande studier av lärares lärande och professionsutveckling menar Timperley (se t.ex. 2011) att kunskaper om elevers lärande är grunden för lärares professionella lärande. Ett kollegi- 
alt samarbete mellan lärare, där lärarna själva väljer och äger ett gemensamt kunskapsobjekt, ger möjlighet för lärare att utveckla en professionell kunskapsbas om elevers lärande. Gemensamma samtal om pågående undervisning kan innebära en sådan möjlighet. Ett gemensamt kunskapsobjekt skulle kunna vara planering, genomförande och utvärdering av ett specifikt undervisningsområde i naturvetenskap. Lärares lärande om undervisning i naturvetenskap gynnas då lärare făr tid och möjlighet till gemensam, kollegial planering och utvärdering av sin undervisning, menar också Simon och Campbell (2012). Även om samtal som process och reflektion som verktyg verkar lovande för lärares utveckling, innebär det en stor utmaning att ifrågasätta och reflektera över sin egen undervisning (Pedder \& James, 2012). I en översiktsartikel om kontextuella faktorers påverkan på lärares bedömningspraktiker, konstaterar Fulmer, Lee och Tan (2015) att faktorer mellan klassrummet och nationell nivå - t.ex. lärares kollegiala samarbete - så kallade meso-effekter, spelar en viktig roll. Trots det, menar de, är det få studier där dessa möjliga influenser specifikt undersökts i relation till förståelse av lärares bedömningspraktik. Dessutom betonar Abell (2007) behovet av fler studier av hur lärares kunskap om bedömning tar sig uttryck vid såväl planering som genomförande av bedömningar i det naturvetenskapliga klassrummet. Likaså är det få av de studier som rör lärares bedömning och betygssättning, som fokuserar på vilket elevkunnande som framstår som centralt för lärare (Lundahl, Hultén, Klapp \& Mickwitz, 2015). En intervjustudie om lärares betygssättning och dokumentation visade olika inriktningar med varierad komplexitet gällande deras tolkning och tillämpning av styrdokument, vetenskaplig grund respektive beprövad erfarenhet (Vallberg Roth, Gunnemyr, Londos, \& Lundahl, 2016). Variationer i bedömningskompetens identifierades utifrån hur lärarna integrerade olika grunder för bedömning, s.k. kunnighetsbedömning, som forskarna sorterar i följande kategorier: "Atomistisk, skiftande och profilinriktad kunnighetsbedömning." (Vallberg Roth et al, 2016, s. 83). Den profilinriktade kunskapsbedömningen är, enligt forskarna, starkare kopplad till styrdokument, vetenskaplig grund och beprövad erfarenhet än de två övriga. De menar vidare att det vid den s.k. skiftande kunnighetsbedömningen ibland framträderen "intuitiv hållning i termer av 'magkänsla"' (a.a., s. 83).

Samtal om bedömning av elevers kunnande i naturvetenskap framstår således som en möjlighet till reflektion kring specifik undervisning genom att de kan fungera som ett verktyg för utveckling av densamma. Möjligheterna torde dock variera beroende på samtalets förutsättningar, såsom huruvida lärarnas samtal är tillfälliga eller en del av en längre, gemensam process i anslutning till pågående undervisning. Föreliggande studie kan bidra till att belysa hur sambandet mellan undervisning, bedömning med dess skilda syften och elevers lärande, kan uttryckas i lärares gemensamma samtal. I ett vidare perspektiv kan studien även bidra med kunskap om vad som möjliggörs i sådana samtal över tid.

\section{Studiens inramning och syfte}

Genom att följa lärarnas organiserade samtal på den egna skolan, i det specifika ämneskollegiet, skapas goda möjligheter att studera stora delar av det kontinuerliga samtalet där lärare gemensamt planerar, genomför och utvärderar sin undervisning samt för skilda syften bedömer elevers kunnande. Studien genomförs inom ramen för lärares ordinarie arbete. Designen i föreliggande studie skapar möjlighet att följa lärarkollegiets löpande hantering av undervisningsrelaterade frågeställningar, till skillnad från t.ex. tillfälliga intervjusamtal med fristående lärare.

Forskningsfrågan är: Vilka kvalitativt skilda sätt att erfara bedömning av elevers kunnande i naturvetenskap kan identifieras i lärares gemensamma samtal om undervisning och elevers lärande?

\section{Metod}

\section{Empirisk design}

Studien bygger på fyra möten där NO-lärare med stöd av forskare samtalade om planering, genomförande och utvärdering av NO-undervisning och elevers lärande i årskurs 8. Huvudfokus i dessa 
möten var planering av ett prov om människokroppen, samt diskussion om resultatet på provet. Med sitt innehållsliga fokus på bedömning valdes dessa möten ut bland en serie av 12 möten som genomfördes inom ramen för ett forskningsprojekt. Ett NO-lärarlag om fyra personer vid en 6-9 skola och fyra forskare samarbetade i detta projekt kring planering och utvärdering av undervisning. Gemensam planering av undervisning skedde vid möten en gång per vecka, då minst en forskare deltog. Mötestid om 75 min var schemalagd för NO-lärarlaget och ersatte andra arbetsuppgifter som ingick i lärartjänsten utöver undervisning. Undervisningen genomfördes under en sammanhängande treveckorsperiod, medan de 12 mötena sträckte sig över ett halvår. Samtliga veckovisa möten dokumenterades genom ljudupptagning. Innehållet i de olika mötena skiftade beroende på när de ägde rum i relation till genomförandet av undervisningen. Den kollegiala situationen erbjöd möjligheter för lärarna att i sitt vardagliga arbete diskutera och reflektera kring sina frågeställningar och pedagogiska överväganden. Lärarna hade tidigare haft ämnesmöten i syfte att framför allt hantera frågor kring materiel knutet till NO-undervisningen. Mötena i studien inleddes utifrån en i förväg bestämd uppgift eller diskussionspunkt, såsom utformning av ett gemensamt summativt prov. Därutöver diskuterades även lärarnas dagsaktuella frågor om pågående undervisning. Vid tidpunkten för studien arbetade lärarna utifrån nya styrdokument. Tolkning och implementering av kursplaner och kunskapskriterier var då en utmaning för lärarna. Detta tillsammans med att mötena huvudsakligen hanterade planering och utvärdering av ett prov, gjorde att diskussionerna till stor del kom att handla om betygssättning. Därigenom synliggörs lärarnas kunskaper om elevernas lärande indikativt i sammanhang av diskussion om undervisning och bedömning.

Studien var en delstudie i ett mer omfattande forskningsprojekt. Lärarlaget hade i fem punkter uttryckt vad de förväntade sig få stöd till att förändra och utveckla genom samarbetet med forskarna i projektet. Flera av punkterna hade direkt anknytning till frågor om bedömning av elevers kunskaper och kunnande. Lärarna hade varierad erfarenhet av NO-undervisning och utöver de naturvetenskapliga ämnena undervisade de även i matematik och/eller teknik. För ytterligare beskrivning av syftet med och genomförande av forskningsprojektet i sin helhet, se (Olin \& Ingerman, 2016).

\section{Fenomenografi och analysprocess}

Vi studerar lärares gemensamma samtal och vilka sätt att erfara bedömning av elevers kunnande i naturvetenskap som kommer till uttryck där. Vår utgångspunkt är att det finns variation i hur bedömning av elevernas kunnande uttrycks kvalitativt, vilket visar sig tydligt i vårt empiriska material. Variationen avser vad som uttrycks innehållsmässigt, men framför allt på vilket sätt lärare uttrycker sig om det specifika innehållet. Vi har valt att använda en fenomengrafisk ansats i analysen för att identifiera och artikulera en uppsättning kvalitativt olika möjliga sätt att erfara bedömning av elevers kunnande i naturvetenskap (Marton \& Booth, 2000).

Fenomenografi har en relationell bas på så sätt att en teoretisk utgångspunkt är att ett visst fenomen erfars inom ramen för konstituerandet av en meningsfull relation mellan individ och fenomen, vilket anknyter till en fenomenologisk tanketradition. En ytterligare grundläggande utgångspunkt, starkt knuten till fenomenografins kunskapsanspråk, är att en relation till ett visst fenomen kan konstitueras på ett ändligt antal kvalitativt skilda sätt, med avseende på vilken mening och struktur som anknyts till fenomenet. Resultatet av en fenomenografisk analys, en uppsättning distinkta och kvalitativt skilda kategorier som beskriver det empiriska materialet i sin helhet är 'fast förbundet' till en kollektiv nivå (Collier-Reed \& Ingerman, 2013), vilket bland annat innebär att det inte ska förstås som kategoriserande av individer utan av just olika möjliga sätt att konstituera en relation till ett specifikt fenomen. I vår studie innebär det att två kvalitativt skilda samtalsinlägg från en och samma lärare är en del av olika kategorier. Fenomenografins anspråk och förhållningssätt pekar också mot en pedagogisk potential (jämför Booth \& Ingerman, 2015), såtillvida att det både finns en ambition och en tradition av att generera konkret pedagogisk utveckling på grundval av fenomenografiska resultat. Detta bygger på att fenomenografiska studier genererar en teoretiskt lokal beskrivning av vad det innebär att erfara 
eller förstå ett specifikt fenomen, vilket gör den rimlig att tillämpa didaktiskt inom ett innehållsligt område där fenomenet är centralt.

Traditionellt har enskilda intervjuer varit det vanligaste sättet att generera data i fenomenografiska studier, även om det finns exempel på både enkät-, uppsatstext- och videobaserade analyser. Materialet i denna studie är dock lärares diskussioner om undervisning i naturvetenskap. Det finns ett fåtal exempel på analyser av samtal och diskussioner i naturalistisk miljö, se exempelvis Booth och Hulthén (2003), samt Ingerman, Linder, Marshall och Booth (2007). Mot bakgrund av dessa exempel, den pedagogiska potentialen och möjligheten att fånga kvalitativa skillnader i förhållande till bedömning av elevers kunnande, användes en fenomenografisk ansats i denna studie.

I en fenomenografisk analys baserad på intervjuer transkriberas dessa först och forskaren läser därefter in sig grundligt. Därefter påbörjas den egentliga analysen, och intervjuerna bearbetas genom att delas upp i meningsenheter, det vill säga delar i intervjuerna där ett liknande fokus upprätthålls. Skiften mellan olika sådana enheter sker ofta spontant eller till exempel som en reaktion på en ny fråga som ställs och den intervjuade byter då fokus. Dessa meningsenheter samlas i en "pool of meaning" där sedan processen för att identifiera olika sätt att erfara påbörjas, till exempel genom att utgå från ett mindre antal meningsenheter som är olika i olika bemärkelser (se till exempel Åkerlind 2005 för en översikt av hur olika forskare beskrivit den fenomenografiska processen). För att räknas som fenomenografisk bör analysen resultera i kategorier som har en tydlig relation till fenomenet, samtidigt som de har en logisk relation till varandra samt är så få som möjligt. I det här fallet utgick vi från samtal mellan flera personer och de fyra samtalen hade olika infallsvinklar och kom från samma grupp fast vid olika tillfällen i en längre process. Eftersom lärarna i studien planerade och utvärderade ett gemensamt prov, stärks dock förutsättningarna för att deltagarna fokuserar på samma fenomen. Dessutom har de gemensamt formulerat ett antal frågeställningar i relation till sitt professionella uppdrag att bedöma elevers kunnande i naturvetenskap. Lärarna betonade då behovet av att utveckla förmågan att tolka, förstå och synliggöra kunskapskriteriernas differentierande värdeord i såväl undervisning som redovisningsformer för bedömning av elevernas kunnande. Vi valde därför att, efter ordagrann transkribering, dela samtalen i ett slags minsta beståndsdelar, vilket var enskilda inlägg av individer eller en grupp av några inlägg som utgjorde en tydlig enhet och från dessa skapa en "pool of meaning”. Detta gav en intressant mängd med tydligt olika infallsvinklar mot det som var vårt fokuserade fenomen: bedömning av elevers kunnande i naturvetenskap. Vår bedömning utifrån tidigare erfarenhet av fenomenografisk analys var att denna mängd var tillräcklig i bemärkelsen att det fanns goda möjligheter att analysen skulle resultera i stabila kategorier, vilket innebär att ytterligare material sannolikt inte skulle tillföra ytterligare kvalitativ variation utan kunna klassificeras i redan identifierade kategorier. Därefter fortskred analysarbetet på ett fenomenografiskt "normalt" sätt, vilket här innebär att kategorierna som framträder i resultatet har sorterats och omsorterats, samt prövats bland författarna till dess att stabilitet har nåtts. Varje kategori karaktäriseras genom att beskriva vad kategorin inte är respektive vad den är, i relation till det fenomen vi studerat. De empiriska exempel som ges i resultatdelen är avidentifierade.

\section{Samtalens innehåll och möteskontext}

I resultatet presenteras en sammanfattning av vad lärare uttrycker i samtalen, det vill säga vilka innehållsliga aspekter som uttrycks. Ett syfte med sammanfattningarna är att synliggöra den möteskontext som lärarna uttrycker sig i och också att öka förståelsen av den helhet som mötena utgör. På så sätt kan transparensen i studien stärkas, till skillnad från om enbart enskilda läraruttalanden redovisas. Transkript av mötena har sammanfattats först kronologiskt och därefter tematiskt, utifrån innehållslig relevans med avseende på bedömning. Med relevant innehåll avses dels vilket kunnande lärarna vill få syn på och dels hur de genererar underlag för det de tolkar och värderar. Forskningslitteratur om bedömningskompetens (t.ex. Abell \& Siegel, 2011), samt våra erfarenheter som lärare och lärarutbildare, har varit stödjande i arbetet. Samtidigt är det lärarnas erfarande - andra ordningens 
perspektiv - som söks, varför sammanfattningarna konstrueras i huvudsak med hjälp av lärarnas benämningar och uttryck. För att öka transparensen i hur den innehållsliga analysen genomförts, redovisas i resultatet exempel på hur lärares inlägg har tolkats och omtolkats.

Notera att termen innehåll används med avseende på samtalets innehåll, således de didaktiska överväganden som lärarna uttrycker, medan termen stoff avser beskrivning av undervisningsinnehållet. I de styrdokument som lärarna i studien relaterar till används däremot begreppet centralt innehåll. Lärarna växlar mellan användning av termerna innehåll och stoff när undervisningsinnehållet åsyftas.

\section{RESULTAT}

Lärarna uttrycker sig om bedömning av elevers kunnande i naturvetenskap, på kvalitativt skilda sätt. Inledningsvis presenteras samtalens karaktär, utifrån vad som framstår som centralt för lärarna i samtalet om elevers kunnande i NO. Därefter belyses skillnaderna i hur lärarna uttrycker sig om fenomenet, med empiriska exempel. Det totala antalet lärarinlägg och dess fördelning över möten redovisas i tabell 1.

Tabell 1. Redovisning av antalet analyserade inlägg fördelade över ingående möten.

\begin{tabular}{|l|l|l|l|l|}
\hline & Möte 1 & Möte 2 & Möte 3 & Möte 4 \\
\hline $\begin{array}{l}\text { Antal lärarin- } \\
\text { lägg }\end{array}$ & 81 & 72 & 75 & 86 \\
\hline
\end{tabular}

\section{Samtalens övergripande karaktär - innehållslig analys}

Innehållet i samtalen berör dels vad som är föremål för bedömning, det vill säga vilket kunnande i naturvetenskap som elever visar, men också den process som ligger till grund för lärarens tolkning. Undervisningsstoffet i denna tematiska sekvens är människokroppen och specifikt hur ämnen transporteras till och från cellerna. Lärarna menar att utmaningarna för eleverna därför handlar om att växla mellan olika organisationsnivåer, såsom mikro- och makronivå. I människokroppen är det cell-, organ- och organismnivå, som lärarna uttrycker att eleverna förväntas relatera till och använda sig av i sina förklaringar. Samtidigt ska eleverna bygga upp en helhetsbild som bygger på förståelse för kroppens kretslopp, och då använda sig av relevanta biologiska begrepp. I detta sammanhang brottas lärarna med balansen mellan att se till adekvat användning av ett naturvetenskapligt språk i elevernas texter och att eleverna visar förståelse för helheten och sammanhanget. Lärarna nämner också kunnande i naturvetenskap som olika förmågor i enlighet med läroplanen, Lgr 11 (Skolverket, 2011), såsom att föra jämförande eller generaliserande resonemang eller att visa tidigare utvecklat kunnande i ett nytt sammanhang.

Lärarna uttrycker sig även om den process och de aktiviteter som associeras till bedömning av elevers kunnande i naturvetenskap. Underlaget som ligger till grund för lärarnas bedömning är dels elevers enskilda, skriftliga uppgifter och dels en implicit bedömning i klassrummet, där lärarna hänvisar till sin "magkänsla” eller "professionella helhetsbedömning”. Lärarna uttrycker att då skriftliga provuppgifter inte har visat det läraren förväntade sig att eleven skulle kunna, så används även den informella bedömningen från lektionsarbetet som komplement. De uttrycker också hur bedömningen kan vara en sammanvägning mellan den uppfattning de har av elevernas kunnande på lektionerna och det eleven presterar i ett skriftligt prov. Intrycket från lektionerna har dock större betydelse när det gäller en elev som läraren uppfattar som kunnig, men inte har visat det i det aktuella provet. En elev som å andra sidan inte visat sitt kunnande i tidigare undervisning, måste visa detta extra tydligt när han eller hon väl visar sitt kunnande i ett skriftligt prov. 
Vidare diskuterar lärarna även dilemmat de ställs inför när eleven visar motstridiga belägg för sitt kunnande. Frågan för lärarna är hur sammanvägningen då kan genomföras, speciellt i relation till det betygsättande uppdraget. Det kunnande eleven visar i skriftliga uppgifter relaterar lärarna till det stoff som varit i huvudsakligt fokus i undervisningen om människokroppen - specifikt hur ämnen transporteras till och från cellerna. Det innebär i det här sammanhanget att lärarna vid sin bedömning ställer högre krav på hur eleverna använder sin kunskap om delsystemen andning och blodcirkulation än om delsystemet matspjälkning, eftersom lärarna har valt att vänta med fördjupning om det senare stoffet till kommande undervisning.

Lärarna diskuterar också vilken betydelse elevens mognad har för prestationen på ett skriftligt prov. De ger uttryck för att elever har olika individuella förutsättningar för att kunna utveckla kunnande, beroende på sin personliga mognad. Möjligheten till att skaffa sig underlag för bedömning och tolka detsamma beskrivs av lärarna i förhållande till de tidsramar de upplever sig ha.

Jag är ute efter hur mycket jobb det blir för mig när jag rättar. Det är därför jag är intresserad av hur vi utformar frågorna, så att jag får se det jag är ute efter. Så att jag på ett enkelt sätt kan se, vad når eleverna. (47:25, möte 2)

I samtalet relaterar de även till den då nyligen införda kursplanen i biologi (Skolverket, 2011), vilken är uppbyggd av följande tre delar; undervisningens syfte, centralt undervisningsstoff samt kunskapskrav. Lärarna diskuterar hur kursplanen och dessa delar kan förstås i relation till undervisning och bedömning av elevernas kunnande i naturvetenskap. Detta visar sig t.ex. vid diskussioner om betygssättning:

Ja,jag upplever inte att jag får svårt att få in det här i det jag tittar på, men jag upplever att jag har svårt att skilja på de här tre nivåerna i typer av uppgifter och i hur eleverna eventuellt svarar på uppgifter. Alltså skillnaden mot förra kursplanen är att där skulle du kunna detta för ett $G$, du skulle kunna det här för ett VG. Nu ska du kunna samma sak fast på olika nivåer och vi har ju inte fått några direktiv om vad de olika nivåerna innebär. (16:17, möte 1)

Ovanstående citat utgör ett exempel på den utmaning det innebär för lärarna att urskilja olika nivåer av kunnande.

\section{Kvalitativt skilda sätt att uttrycka sig i samtalet}

Ovan beskrivna innehåll används och uttrycks av lärarna på kvalitativt skilda sätt i relation till bedömning av elevers kunnande i naturvetenskap. Dessa tre kvalitativt skilda sätt att erfara, har identifierats som: ett instrumentellt, ett relationellt respektive ett ömsesidigt samspelande förhållningssätt, med avseende på bedömning av elevers kunnande i naturvetenskap.

\section{Ett instrumentellt förhållningssätt}

I det instrumentella förhållningssättet uttrycker lärarna sig antingen om elevernas kunskaper som fristående från sitt sammanhang, eller om hur grunden för bedömning har skapats och organiserats.

Läraren i exemplet nedan, uttrycker sig om vad som bedöms. Utifrån sin tolkning av olika elevsvar från samma elev och provtillfälle, belyser hen att eleven uppvisar divergerande kunnande om människokroppen vid olika frågor. Det visar sig genom att eleven ibland ger beskrivningar på organnivå och ibland på cellnivå. Läraren säger:

Alternativt att de $i$ vissa frågor bara hamnar på lunga, alltså organnivå. På vissa frågor hamnar de på cellnivå. Hur sjutton gör jag min bedömning där? När eleven i vissa lägen kanske kommer till ett steg och $i$ andra lägen mycket längre. Vad anser jag då att eleven når till? (50:09, möte 2). 
Elevens varierande användning av skilda [biologiska] organisationsnivåer skapar således svårigheter för läraren med avseende på hur elevens kunnande kan sammanfattas. Det framträder då hen uttrycker dilemmat med hanteringen av "bevisbördan" gällande vilken kunskapsnivå elevsvaren sammantaget motsvarar. Kunskapen tas för given, således vilket naturvetenskapligt kunnande eleven förväntas visa. I följande två inlägg har den konkreta nivån med exempel på elevuttryck lämnats och istället är bedömningsprocessen i fokus. Eleverna har genomfört ett prov och läraren beskriver det arbete som ligger till grund för det sammanfattande betyg som hen har kommit fram till. Bedömningsunderlaget bygger på olika tillfällen i undervisningen i klassrummet, såsom diskussion och samtal, men också på det eleven skrivit i det aktuella provet:

Många av dem och det är ju liksom en mix, för jag satt och funderade lite grann på vad jag liksom sett av dem på lektioner när vi har diskuterat och pratat och sådant där också. Jag gjorde som en liten bedömning för mig själv innan jag satt och rättade och kollade och lade upp de här i olika högar. Bedömningen av det där är väl en mix med det man kommer ihåg att eleverna har gjort på lektionerna i förhållande till vad eleverna skriver och visar på det där när man sätter upp betyg för sig själv. (51:52, möte 3)

Läraren beskriver alltså här bedömningsprocessen, hur organisationen kring bedömningen går till. Underlaget för den sammantagna bedömningen av elevens kunnande grundar sig dels i hens erfarenheter från klassrummet och dels i det genomförda skriftliga provet. Vilket kunnande och eller vilka kunskaper som läraren bedömer är implicit, vilket kan tolkas som att lärarens bedömning grundar sig i en intuitiv uppfattning i stunden om elevers kunnande i naturvetenskap. Även i följande inlägg från det andra uppföljande mötet hamnar det konkreta kunnandet som eleven visat, helt i bakgrunden. I mötet diskuteras specifika elevexempel, men inledningsvis lyfter en av forskarna frågan om relationen mellan konstruktionen av provuppgifterna och kunskapskraven, således vilka belägg för elevers kunnande som kan synliggöras i elevsvaren. Läraren redogör för sitt tillvägagångssätt vid bedömning av elevers kunskaper och säger:

Ja, om jag minns, så gjorde jag så att jag rättade Barbapappa [öppen fråga] för sig och jag rättade det här andra prov-, alltså kryssalternativen för sig. Så lade jag in dem i fyra olika högar vad jag tyckte att de motsvarade, alltså $F, E$, C och A i någon form. Så försökte jag kombinera ihop. Om det var två C på bägge delarna så blev det naturligt C. Och så parade jag ihop det, så jag hittade de här. Vad de betygen borde ligga på, kan man säga. (20:13, möte 4)

Läraren uttrycker sig alltså här om det betygssättande uppdraget, och exemplet visar att organisation och dokumentation sätts i förgrunden. Trots att samtalets planerade fokus var att ta reda på vad eleverna kunde, tar den administrativa logiken över genom projicering på konkreta modeller såsom att 'sortera i högar och lägga ihop'. Uttalandet skiljer sig innehållsligt men inte kvalitativt från nästa läraruttalande om hur en av lärarens elever har presterat bättre i provuppgiften än han brukar. Lärarens förklaring till detta är att eleven har haft nytta av erfarenheter från sitt fritidsintresse för dykning, när kunnande om människokroppen förväntas visas. Vid upprepade tillfällen uttrycks kunnandet i naturvetenskap som "det här" utan närmare specificering av vad det är eller innebär. Läraren ger däremot exempel på situationer där andra kvaliteter av kunnande har visat sig, såsom i läxor eller när läraren resonerat med eleven:

Fredrik, det är en kille som inte anstränger sig. Han har mycket med sig själv. Han har stenkoll på väldigt mycket inom NO, men de traditionella läxorna... Han gör precis bara så han får näsan ovanför vattenytan, men när man resonerar och när man... Han har inte läst på det här, men det mesta är ju riktigt. Det är blodomloppet som är fel ritat och han har då dykcertifikat och liksom har en praktisk sida av det här med syre, så han kan ju det här. Men han har betyget, vad blir det.. E och så ovanför det. D heter det va? Ja, men han skulle mycket väl kunna ha... Men det visar han sällan. Men det här har han liksom gjort utifrån andra förutsättningar. Han har inte behövt pluggat. Han kan det här, ganska bra. (50:58, möte 4) 
Innehållsligt i ovanstående inlägg från läraren nämns både kunnande och tillfällen som hen har för att skapa sig en bild av elevens kunnande. Läraren benämner elevens visade kunnande i allmänna ordalag: "det mesta är riktigt" och "han kan ju det här". Däremot uttrycks felaktigheter explicit, då hen säger att "Det är blodomloppet som är fel ritat".

Ett instrumentellt förhållningssätt till bedömning av elevers kunnande i naturvetenskap innebär framför allt fokus på administrativa bedömningsmodeller. Utmaningen och även frustration i bedömningsarbetet framträder tydligt då läraren uttrycker: " Hur sjutton gör jag min bedömning där? ”. Då lärarna uttrycker sig om elevkunnandet i sig sker det implicit och snarare i bristperspektiv, således vad eleven inte visar. Ovanstående inlägg skiljer sig kvalitativt från inlägg där såväl kunnande som bedömningsprocessen problematiseras och sätts i relation till varandra, vilket belyses i nästa kategori.

\section{Ett relationellt förhållningssätt}

I ett relationellt förhållningssätt uttrycker sig således lärarna om elevers kunnande i naturvetenskap och bedömningsprocessen $i$ relation till varandra. Genom att en aspekt tas för given kan relationen beskrivas som enkelriktad, där fenomenet problematiseras utifrån ena aspektens perspektiv. Lärarna uttrycker sig således med olika utgångspunkt, vars respektive innebörd beskrivs i följande två kontrasterande exempel. I det första exemplet av inlägg tas det som ska bedömas, bedömningens objekt, för givet och sätts således i förgrunden. Läraren beskriver hur en elev vid olika tillfällen visar olika kunnande om skilda organ eller organsystem:

Alltså om man ska resonera som så att har de visat på något område att man ... Säg att vi bara har evolution inom biologin på vårterminen i nian, och vi inte läser något annat inom biologi. Om eleven där visar att man når upp till ett $A$ så sätter man ett A även om eleven vid alla andra terminerna jobbat för ett E. Men om man resonerar som så att man ska tänka sig att eleven har det som den uppvisar just då så kan ju eleven skita $i$ att göra saker och ting fram tills det absolut sista, och då lägga ner jättemycket krut på det eller? Eller tänker jag tokigt? ... Om de kunskaperna och det de gör nu inte ska vara med och inräknas i de betygen de får, så har jag inte riktigt, så har jag missuppfattat hur Skolverket formulerar sig. Om jag har en elev som för mig inte har visat att de har nått upp till mer än E i förståelsen av lungor och hjärta och den biten, men sedan kanske visar när vi pratar matspjälkningssystemet att de har förstått mycket, mycket mer. Men då har jag ju bara belägg kanske för att de förstår tunntarmen, tjocktarmen och levern, medan jag nu har gjort hjärta och lungor och de bitarna. Men ska jag då.. alltså. (52:04, möte 2).

Elevens kunnande i naturvetenskap (specifikt människokroppen), beskrivs här ovan sekvenserat genom att det handlar om kunskap som att visa förståelse för ett antal organ i kroppen. Läraren uttrycker sig även om betygsnivåer och det dilemma lärare har, i att avgöra hur dessa skilda nivåer av kunnande ska vägas samman till ett betyg. Utgångspunkten som läraren tar pekar mot att hen tar kunskapen och kunskapsnivåerna i sig för givna, medan fokus istället riktas mot den process som möjliggör för läraren att få kunskap om elevers kunnande. Utmaningen för hen ligger framför allt i hur ett, över tid, föränderligt och därmed motstridigt underlag om elevens kunnande kan förstås och hanteras i sammanhanget. Detta innebär att bedömningens objekt står i förgrunden och tas för givet. Det påverkas därmed inte av resonemanget och problematiseringen av bedömningsprocessen. Men vad som tas för givet i det läraren uttrycker om relationen mellan elevers kunnande och processen kan också vara det omvända. Läraren i exemplet nedan utgår från det som eleverna har visat i en skriftlig uppgift på ett prov, således ett av de skriftliga underlag läraren har skaffat sig för att kunna bedöma elevernas kunnande i naturvetenskap. Läraren säger: 
För det märkte ju jag. Jag har inte rättat, men jag har tittat på prov på ett antal, bara för att se. Och skulle jag göra det här nu, så skulle jag göra det lite annorlunda. För när man tittar på Barbapappa så är det en del som har ritat väldigt bra och fått ihop dem och så är det en del som skrivit väldigt bra och så är det en del som har lyckats med både skriva och rita bra och har det något mervärde i det. Men så börjar man titta på det här [relaterar till kursplanen och kunskapskraven]. Det är ju ändå inte många saker som man kan säga är på någon A-nivå utav det här. Utan det där är möjligen en väl utvecklad motivering, står det om på A-nivå... och beskriva komplexa samband... det är väl egentligen nästan bara det... lite grann generaliseringar kring energiflöden och kretslopp - jag vet inte om det går att dra några generella slutsatser, så att det är ju. Är man riktigt duktig så kanske man når de här... men samtidigt så såg jag på .. väldigt många kan det här som vi vill att de skulle kunna. (4:26, möte 3).

Läraren identifierar i detta inlägg att elever antingen har ritat eller skrivit bra, eller både ritat och skrivit bra. Således nämner hen olika former för kunskapsuttryck. Läraren relaterar sedan till styrdokumenten och de skrivningar som finns för respektive betygsnivå. Hen jämför med elevernas resultat på generell nivå, genom att tala om kunskaperna som "det här". I sista meningen uttrycker läraren att det kan finnas möjlighet att nå det angivna kunskapskravet, men menar samtidigt att många elever kan det hen har förväntat sig. Läraren uttrycker att eleverna har visat det kunnande som hen menar förväntats, samtidigt som detta inte överensstämmer med och passar i mallen för kunskapskraven. Det framstår som att bedömningsprocessen står i fokus och tas för given, men att olika kunnande kan visa sig genom den uppgift eleven har fått.

\section{Ett ömsesidigt samspelande förhållningssätt}

I ett ömsesidigt samspelande förhållningssätt relaterar lärarna flera dimensioner av såväl elevers kunnande eller kunskap i och om naturvetenskap, som bedömningsprocessen och organiserande faktorer till varandra. Dessutom görs detta på ett sådant sätt att ingen aspekt av fenomenet tas helt för given, utan att sambandet mellan dem istället problematiseras och deras innebörd omförhandlas i ljuset av varandra. En av lärarna uttrycker en uppfattning om att eleven kan mer än han/hon visar i konkreta handlingar, texter etc. Hen uttrycker följande vid planeringen av det skriftliga provet:

Om man bara låter frågan vara öppen. Och sedan så har jag suttit och bedömt den elev som HAR kommit på det här.. och så vet jag: Det här hade du ju också förmodligen kunnat redogöra ... och det är ju lite ... fel.. utan man måste ju liksom styra in de på och tala om: Det här vill jag veta något om... och sedan formulera.. det här vill jag veta om du vet något om. (40:33, möte 1).

Inlägget föregicks av en diskussion om hur man kan få eleverna att uttrycka de komplexa sambanden som läraren efterfrågar. Hen beskriver här den tydlighet som krävs i olika steg i lärarens arbete med bedömningar av elevers kunnande. Först och främst att uttrycka vad det är som bedöms, men också utmaningen i att få eleven att både förstå vilket kunnande som efterfrågas och på vilket sätt det kunnandet kan visas. I den sista meningen sätter läraren ord på detta, där hen säger "det här vill jag veta något $\mathrm{om} / .$. /det här vill jag veta om du vet något om”. Läraren gör därmed en distinkt skillnad mellan kunnandet i sig och att detta kunnande förväntas visas i någon uttrycksform. Genom distinktionen blir det även tydligt att relationen mellan vad som bedöms, och den process som hör till bedömningen, står i direkt relation till varandra.

Vid uppföljningen av provet, där diskussionen sker i relation till konkreta exempel på elevsvar, inleder en av lärarna med en beskrivning av naturvetenskapligt kunnande genom att belysa dilemmat i att bedöma språkliga detaljer eller helheten i sammanhanget. Eleven använder sig av ord och uttryck som inte stämmer helt överens med ett naturvetenskapligt sätt att uttrycka sig, men samtidigt menar läraren att eleven har förstått den övergripande principen för vad som faktiskt händer med maten vi 
äter:

Det är ju lite om man ska gå på det rent språkliga eller om man kan se av helheten om de har förstått.. för jag har ju något liknande här då. Carl, som här skriver, ja det mesta är riktigt, han skriver: "Maten går ner i magen och kroppen gör om maten till socker” Jag menar, gör om, då förstår jag ju att han menar det, men vi har ju inte egentligen ens gått igenom liksom den här metabolismen i magen, så jag kan inte ens förvänta mig att han ska kunna det här, för det hoppade jag över i alla fall, det här med matsmältningen. (25:12, möte 4).

Läraren relaterar elevens skriftliga beskrivning till den undervisning som har bedrivits, då hen säger att de inte har haft undervisning om matspjälkningen. På så sätt kontextualiseras elevens prestation till de möjligheter som eleven har haft att utveckla sin förmåga att beskriva vad som händer med maten. Därmed tolkas elevens naturvetenskapliga kunnande i relation till den undervisning som eleven varit med om. Bedömningsprocessen och elevens kunnande relateras till varandra och den kontext som eleven och läraren befinner sig i. Både lärare och elev kan därmed betraktas som aktörer med möjlighet att påverka situationen. Här relateras elevens kunnande till undervisningen och vad den har erbjudit för möjligheter för eleven att lära sig. Det skiljer sig från exemplet i ett relationellt förhållningssätt, där undervisningen istället har varit ett tillfälle för (implicit) bedömning.

Ett annat exempel är när lärarna diskuterar relationen mellan undervisning och bedömning, med utgångspunkt i vilka förmågor det är som läraren i sin undervisning dels ska skapa förutsättningar för eleven att utveckla och dels ska bedöma. De diskuterar också hur kursplanen i biologi kan läsas både i sina olika delar och i sin helhet. Lärarna uppehåller sig vid hur det specificerade ämnesstoffet i kunskapskravet kan läsas i relation till ämnesstoffet som omskrivs i det så kallade centrala innehållet. En av lärarna ifrågasätter tidigare diskussionsinlägg om tolkningen av hur kursplanens olika delar är tänkta att användas, och uttrycker i följande två inlägg en annan bild av detta:

Så har jag aldrig fått det förklarat för mig, att det är det man ska tänka på. Jag har varit inne på att man ska vara inne på det centrala innehållet $i$... att det är det som du ska fokusera undervisningen på, och inte på kunskapskraven. (55:02, möte 2).

Samtalet om tolkning av kursplanen fortsätter därefter. En stund senare i diskussionen uttrycker läraren sig om relationen mellan val av ämnesstoff och de förmågor, som undervisningen ska skapa förutsättningar för elever att utveckla:

Det blir ju en liten annan tanke på hur sjutton man undervisar om man tänker att på det här avsnittet tränar jag på den här förmågan, för eleverna. Så råkar det vara det här stoffinnehållet. Så det är olika stoffinnehåll som passar olika bra när man tränar olika förmågor hos eleverna. (1:03:22, möte 2).

Läraren relaterar till det som ligger till grund för elevens möjlighet att utveckla den förmåga och det kunnande som sedan ska bedömas. Även om inte mer uppenbara aspekter av bedömning nämns, så kan inlägget tolkas i sammanhang av bedömning. Läraren kontextualiserar elevers kunnande än mer i och med att förmågan också relateras till val av stoff. Detta uttalande skiljer sig markant från andra inlägg där lärare snarare tar utgångspunkt i vad de uttrycker som elevers mognad, som en förutsättning för elevens kunnande.

\section{DisKussion}

Studiens syfte var att identifiera kvalitativt skilda sätt att erfara bedömning av elevers kunnande i naturvetenskap, inom ramen för gemensam planering och utvärdering av undervisning. Vår analys visar att lärarna i de kollegiala samtalen uttrycker sig om samma innehåll men på kvalitativt skilda 
sätt. Skillnaden framträder i hur de talar om aspekter av bedömning och relationen mellan dem. När kunskap och/eller det kunnande eleverna visat relateras till den undervisning som genomförts i klassrummet, öppnar det för ett förhållningssätt där undervisning och bedömning ses som beroende av varandra. På så sätt kontextualiseras elevens kunnande och möjligheten till ett komplext och dynamiskt kunskapsbegrepp framträder i och med lärares reflektion över det ömsesidiga samspelet mellan undervisning och bedömning. Detta förhållningssätt återfinns i lärarnas samtal i vår studie, men betydligt vanligare är ett instrumentellt sätt att uttrycka sig om bedömning av elevers kunnande. I det senare sätts fragmenterad kunskap i fokus, vilket tenderar att förenkla innebörden av kunskap i och om naturvetenskap.

Studiens empiriska material indikerar därmed att lärarnas fokus på sammanvägning av elevers kunnande till ett betyg riskerar att generera just ett sådant instrumentellt förhållningssätt till bedömning, även om denna slutsats inte är ett direkt resultat av analysen. I vår studie uttrycker sig lärarna om elevens kunnande i huvudsak som kunnande om olika tematiska områden snarare än hur stoffet hanteras av eleven i en specifik situation eller i förhållande till olika problemställningar. Det pekar mot att innebörden av elevens kunnande hamnar i bakgrunden, till förmån för ett administrativt fokus på dokumentation i form av betyg. Det visar sig när lärarna skiftar från tolkning och värdering av elevers specifika kunskapsuttryck i skriftliga provuppgifter till en sammanvägning av elevens kunnande i ett betyg. Detta påminner om den s.k. "atomistiska kunskapsbedömning” som Vallberg Roth et al (2016) kom fram till i sina intervjustudier (s. 83). I vår studie framträder i det skedet ett icke artikulerat och enskilt lärararbete som leder fram till och kan benämnas med det lärarna i studien kallar "magkänsla" eller "lärares professionella helhetsbedömning”. Denna "magkänsla” refererar också lärarna till i studien av Vallberg Roth et al (2016). I vår studie synliggörs då skillnader i tolkning och användning av styrdokumenten, här kursplanen i biologi. I ett instrumentellt förhållningssätt till bedömning framträder en fragmenterad tolkning av kunskapskriterierna genom fokusering av dess separata delar, såsom när elevers kunnande om enskilda organ adderas till varandra. Undervisningens innehåll tenderar därmed att likställas med det eleven förväntas kunna. När undervisning och bedömning av elevers kunnande istället erfars som ömsesidigt samspelande, kan undervisningens tematiska innehållssekvenser ses som gemensamt bidragande till elevers utveckling av förståelse för naturvetenskap och dess karaktär. Det senare visar sig när lärarna i vår studie reflekterar över sambandet mellan urval av undervisningsstoff och elevers möjligheter att utveckla önskvärda förmågor inom skolans naturvetenskap. Utifrån de kvaliteter som ligger i att kunna erfara undervisning och bedömning av elevers kunnande som ömsesidigt samspelande, drar vi slutsatsen att det är önskvärt och viktigt att ett sådant sätt att erfara visar sig i (åtminstone ibland) i lärares gemensamma samtal. Detta inte minst för att den reflektion och problematisering det öppnar för ska kunna bidra till utveckling av lärares kompetens och därmed hög kvalitet i deras dagliga arbete.

I samband med betygssättning förväntas elevers kunnande bedömas på ett likvärdigt och allsidigt sätt samtidigt som bedömningens olika syften skall hanteras. I svårigheter att hantera båda, riskerar bedömning i formativt syfte - för såväl enskilda elevers lärande som för utveckling av undervisningen - att överges eller begränsas till förmån för betygssättning. Det senare är i vissa perspektiv logiskt, eftersom betygssättning är ett myndighetsuppdrag med krav på likvärdig bedömning. Här framträder således en spänning mellan vad som i ett bredare perspektiv å ena sidan kan betraktas som ett bildningsperspektiv på elevernas utveckling inom naturvetenskap, och å andra sidan en myndighetsutövning relativt den målstyrda skolan med definierade kunskapskrav som inte alltid stämmer överens med det kunnande lärarna identifierar i elevernas kunskapsuttryck. Lärarkollegiets gemensamma identifiering av kvalitativa skillnader i elevers kunnande i naturvetenskap kan förmodas stödja lärares verbalisering av kunnande och i förlängningen bidra till ökad transparens och likvärdighet vid betygssättning.

\section{Möjligheter i samtal om bedömning och undervisning}

Studien bidrar till förståelse för lärares sätt att erfara bedömning av elevers kunnande i naturveten- 
skap, inom ramen för gemensam, kollegial planering och utvärdering av undervisning och elevers lärande. Förekomsten av ett ömsesidigt samspelande förhållningssätt till bedömning har betydelse för samtalets kvalitet och potentiella utveckling, såsom möjlighet att omförhandla sin egen förståelse av bedömning. Artikulering av det tysta och enskilda bedömningsarbete som lärarna gemensamt ägnar sig åt i vår studie, har beskrivits som nödvändigt för att kunna diskutera samband mellan vad elever ska lära sig och planering och utvärdering av undervisning (Quartz et al., 2014). I vår studie reflekterar lärarna utifrån autentiska elevtexter, bl.a. över sambandet mellan lärares urval av naturvetenskapligt stoff och den förmåga undervisningen syftar till att ge eleverna möjlighet att utveckla. De diskuterar dessutom innebörden av elevers kunnande inom ramen för sin egen bedömningspraktik. Lärares bedömningskompetens skall ses och förstås i relation till det specifika sammanhang och den kontext som läraren verkar i, enligt Willis et al. (2013). Den kollegiala situationen skulle alltså kunna vara en arena för lärares lärande och utveckling av bedömningskompetens (Abell \& Siegel, 2011; Popham, 2009; Willis et al., 2013) och Carlgren och Marton (2000) menar att diskussioner av sambandet mellan undervisning och lärande kan bidra till utveckling av en gemensam professionell kunskapsbas. Vår studie är dock begränsad till att lärarna diskuterar om sin undervisning utan att, eller i ringa omfattning, ha varit i varandras klassrum. Däremot har de formulerat gemensamma mål och genomfört ett gemensamt utvärderande prov, vilket ger en indirekt diskussion även om genomförd undervisning. Simon och Campbell (2012) betonar att när lärare ges tid för gemensam planering och utvärdering av undervisning i naturvetenskap kan lärares lärande gynnas. Vår studie bidrar med vilket innehåll som då kan framträda som centralt för lärarna.

\section{Tack}

Studien har genomförts inom ramen för VR-UVK-projektet: Supporting Teachers' Agency and Learning in Teaching Secondary School Science (2011-2013). Stort tack till forskarkollegor och medverkande lärare.

\section{Referenser}

Abell, S. (2007). Research on Science Teacher Knowledge. In S. Abell \& N, Lederman (Eds.), Handbook of research on Science Education (pp. 1105-1149). New Jersey \& London: Lawrence Erlbaum Associates.

Abell, S., \& Siegel, M. (2011). Assessment Literacy: What Science Teachers Need to Know and Be Able to Do. In D. Corrigan, R. Gunstone \& J. Dillon (Eds.), The Professional Knowledge Base of Science Teaching (pp.205-221). Dordrecht: Springer. Doi: 10.1007/978-90-481-3927-9_12

Booth, S., \& Hulthén, M. (2003). Opening dimensions of variation: An empirical study of learning in a Web-based discussion. Instructional science, 31(1-2), 65-86. Doi: 10.1023/A:1022552301050

Booth, S., \& Ingerman, Å. (2015). The Pedagogical Potential of Phenomenography for Teacher Practice and Teacher Research. In P. Burnard, B-M. Apelgren \& N. Cabaroglu (Eds), Transformative Teacher Research. Theory and Practice for the C21st. (pp. 25-38). Rotterdam: Sense publishers.

Carlgren, I., \& Marton, F. (2000). Lärare av i morgon. Pedagogiska magasinets skriftserie, nummer ett. Stockholm: Lärarförbundets förlag.

Collier-Reed, B., \& Ingerman, A. (2013). Phenomenography: From critical aspects to knowledge claim. In J. Huisman \& M. Tight (Eds.), Theory and Method in Higher Education Research. (International Perspectives on Higher Education Research, Volume 9, pp. 243-260). Bingley, UK: Emerald. doi: 10.1108/S1479-3628(2013)0000009016

Edwards, F. (2013). Quality assessment by science teachers: Five focus areas. Science Education International. 24(2), 212-226.

Fulmer, G., Lee, I., \& Tan, K. (2015). Multi-level model of contextual factors and teachers' assessment practices: an integrative review of research. Assessment in Education: Principles, Policy \& Practice, 1-20. doi: 10.1080/0969594X.2015.1017445

Gustafsson, J. E., Cliffordson, C., \& Erickson, G. (2014). Likvärdig kunskapsbedömning i och av den 
svenska skolan: problem och möjligheter. Stockholm: SNS förlag.

Ingerman, Å., Linder, C., Marshall, D., \& Booth, S. (2007). Learning and the variation in focus among physics students when using a computer simulation. NorDiNa, 3(1), 3-14.

Lederman, N., \& Lederman, J. (2012). Nature of Scientific Knowledge and Scientific Inquiry: Building Instructional Capacity through Professional Development. In B. J. Fraser, K. Tobin \& C.J. McRobbie (Eds.), Second International Handbook of Science Education (pp. 335-359). Berlin: Springer. Doi: 10.1007/978-1-4020-9041-7_24

Lyon, E. (2013). Conceptualizing and Exemplifying Science Teachers' Assessment Expertise, International Journal of Science Education, 35(7), 1208-1229. doi: 10.1080/09500693.2013.770180

Lundahl, C., Hultén, M., Klapp, A., \& Mickwitz, L. (2015). Betygens geografi: forskning om betyg och summativa bedömningar i Sverige och internationellt. Delrapport från skolforsk-projektet. Stockholm: Vetenskapsrådet.

Magnusson, S., Krajcik, J., \& Borko, H. (1999). Nature, sources and development of pedagogical content knowledge for science teaching. In J. Gess-Newsome \& N. G. Lederman (Eds.), Examining pedagogical content knowledge: The construct and its implications for science education (pp.95-132). Boston: Kluwer. Doi: 10.1007/0-306-47217-1_4

Marton, F., \& Booth, S. (2000). Om lärande. Lund: Studentlitteratur.

Olin, A., \& Ingerman, Å. (2016). Features of an Emerging Practice and Professional Development in a Science Teacher Team Collaboration with a Researcher Team. Journal of Science Teacher Education, 27(6), 607-624. Doi: 10.1007/S10972-016-9477-0

Pedder, D., \& James, M. (2012). Professional Learning as a Condition for Assessment for Learning. In J. Gardner (Eds.), Assessment and learning. 2. ed. (pp. 33-48). London: SAGE.

Popham, W. (2009). Assessment literacy for teachers: Faddish or fundamental? Theory into practice, 48(1), 4-11. Doi: 10.1080/00405840802577536

Quartz, K., Kawasaki, J., Sotelo, D., \& Merino, K. (2014). Supporting assessment autonomy: How one small school articulated the infrastructure needed to own and use student data. Journal of Educational Change, 15(2), 125-152. Doi: 10.1007/s10833-013-9219-4

Simon, S., \& Campbell, S. (2012). Teacher learning and professional development in science education. In B.J. Fraser, K. Tobin \& C. J. McRobbie (Eds.), Second International Handbook of Science Education (pp. 307-321). Berlin: Springer. Doi: 10.1007/978-1-4020-9041-7_22

Skolverket, (2011). Läroplan för grundskolan, förskoleklassen och fritidshemmet. Stockholm: Fritzes.

Timperley, H. (2011). Realizing the power of professional learning. London: Open University Press.

Vallberg Roth, A. C., Gunnemyr, P., Londos, M., \& Lundahl, B. (2016). Lärares förtrogenhet med betygssättning. Malmö: Malmö Högskola.

Wallace, J., \& Loughran, J. (2012). Science teacher learning. In B. J. Fraser, K. Tobin \& C.J. McRobbie (Eds.), Second international handbook of science education (pp. 295-306). Berlin: Springer. Doi: 10.1007/978-1-4020-9041-7_21

Wiliam, D. (2010). An integrative summary of the research literature and implications for a new theory of formative assessment. In H. L. Andrade, \& G.J. Cizek (Eds.), Handbook of formative assessment (pp. 18-40). New York \& London: Routledge.

Willis, J., Adie, L., \& Klenowski, V. (2013). Conceptualising teachers' assessment literacies in an era of curriculum and assessment reform. The Australian Education Research, 4O(2), 241-256. Doi: 10.1007/s13384-013-0089-9

Åkerlind, G. (2005). Variation and commonality in phenomenographic research methods. Higher Education Research \& Development, 24(4), 321-334. Doi: 10.1080/07294360.2011.642845 